\title{
Biology of little tunny Euthynnus alletteratus in the Gulf of Gabes, Southern Tunisia (Central Mediterranean Sea)
}

Biología de la bacoreta Euthynnus alletteratus del Golfo de Gabes, Sur de Túnez (Mar Mediterráneo Central)

\section{Ghailen Hajjej ${ }^{1}$, Abdallah Hattour ${ }^{1}$, Hassen Allaya², Othman Jarboui ${ }^{1}$ and Abderrahmen Bouain ${ }^{3}$}

\author{
${ }^{1}$ National Institute of Marine Sciences and Technologies (I.N.S.T.M), 3018 Sfax, Tunisia. ghailen3@yahoo.fr \\ ${ }^{2}$ Faculty of Sciences of Tunis, University Campus, 2092 El Manar, Tunis, Tunisia \\ ${ }^{3}$ Faculty of Sciences of Sfax, Soukra Road km 4, BP 802-3038 Sfax, Tunisia
}

\begin{abstract}
Resumen. - Se describen algunos parámetros biológicos de la bacoreta Euthynnus alletteratus en el Golfo de Gabes (sur de Túnez), tales como la proporción de sexos, el Índice Gonado-Somático (IGS), el Índice Hepato-Somático (IHS), la longitud de primera madurez sexual, y la relación longitud-peso. Se analizó un total de 397 specímenes (244 hembras y 153 machos) entre los 36,7 y $97,8 \mathrm{~cm}$ de longitud, con un promedio $52,29 \pm 5,87 \mathrm{~cm}$. Las muestras se recolectaron mensualmente, entre enero de 2008 y diciembre de 2009 . El $61 \%$ de los ejemplares fueron hembras. El periodo de desove se extiende de junio a septiembre, calculado a partir de los altos valores de IGS. Las relaciones longitud-peso revelaron que la bacoreta presenta una alometría negativa. La longitud promedio de primera madurez de las muestras tomadas en el Golfo de Gabes fue de $44,8 \mathrm{~cm}$ de longitud de horquilla para las hembras y $42,8 \mathrm{~cm}$ para los machos.
\end{abstract}

Palabras clave: Indice Gonado-Somático, Iongitud de primera madurez, relación Iongitud-peso

\begin{abstract}
Biological features known as sex-ratio, Gonad-Somatic Index (GSI), Hepatic-Somatic Index (HSI) and size at first sexual maturity, and the length-weight relationships (LWR) were studied in little tunny, Euthynnus alletteratus, caught in the Gulf of Gabes (Southern Tunisia). A total of 397 little tunny ( 244 females and 153 males) were analysed. Fish length ranged between 36.7 and $97.8 \mathrm{~cm}$, average $52.29 \pm 5.87 \mathrm{~cm}$. Samples were monthly fished from J anuary 2008 to December 2009. Sixty one percent of the specimens caught were females. The high GSI suggest that the spawning period runs from J une to September. Fish in spawning condition are to be observed in August since GSI reaches the peak in J uly. Negative allometry was found in little tunny. Fork length at first sexual maturity in males $(42.8 \mathrm{~cm})$ was smaller than in females $(44.8 \mathrm{~cm})$.
\end{abstract}

Key words: Gonad-Somatic Index, size at first sexual maturity, length-weight relationship

\section{INTRODUCTION}

Little tunny (Euthynnus alletteratus Rafinesque, 1810) is the only species belonging to the genus Euthynnus that occurs in Tunisia (Hattour 2000). This coastal species primarily occurs in Tunisia throughout the year, with frequently variation in occurrence. Large catches are recorded in May, June and July (Hattour 2000). Little tunny in Tunisia is thought to be part of the Mediterranean stock, due to lack of thorough assessment. However, Rey \& Cort (1981) showed that an outer little tunny stock, different from that in the Mediterranean Sea does exist, considering the tagging results, which undoubtedly suggest possible little tunny migration into the Atlantic Ocean, from the Mediterranean Sea, through the Strait of Gibraltar.
There are several studies of biological features of little tunny (such as length at first sexual maturity, gonadsomatic index, fecundity, sex-ratio, spawning period, growth, age, length-weight relationships, length and weight frequency distributions) (Frade \& Postel 1955, Landau 1965, Rodriguez-Roda 1966, 1979, Klawe et al. 1970, Diouf 1980, Cayre \& Diouf 1983, Kahraman \& Oray 2001, Kahraman 2005, Macias et al. 2006, Kahraman et al. 2008, Macias et al. 2009), however, scarce knowledge about little tunny exists for Tunisian coast, despite the fact its fishery importance. The only data accessible to everyone and dealing with the biology of this species in Tunisia are those of Hattour (1984, 2000, 2009) and Hajjej et al. (2009). 
Therefore, the present study aims to analyze the biological traits of little tunny caught off the Gulf of Gabes, one of the most productive fishing areas in Tunisia (Bradai et al. 1995). The current data are of a great importance for better knowledge of little tunny in Tunisia.

\section{Material AND MEthods}

Random samples were taken monthly from a commercial fishery in the Gulf of Gabes, which extends from Ras Kapoudia (on parallel $35^{\circ} \mathrm{N}$ ) to the Tunisian-Libyan border (Fig. 1), from January 2008 to December 2009. Total samples numbered 397 specimens ranging in size from 36.7 to $97.8 \mathrm{~cm}$ of fork length (here after expresed as L) (mean $52.29 \pm 5.87 \mathrm{~cm}$ ). Fishes were caught in various gears (purse seine, gill nets, longlines, trawls and beach seine). Specimens were measured to the nearest centimetre fork length, using a measuring board and weighed prior to dissection (total weight, $\mathrm{Wt}$ ). Fish were sexed by macroscopic examination of the gonad (degree of opacity, consistency, oocytes or sperm occurrence as well as the overall colouring of gonads) when dissected out and subsequently weighed (We). Gonad and liver were also weighed on a digital balance with $0.01 \mathrm{~g}$ accuracy. The maturity stage of gonad was assessed using a developmental scale ranging from immature (stage I) to spent (stage V) (Diouf 1980).

Sex-ratio (SR) was calculated as the proportion of females. The population sexual structure was examined using a chi-squared significance test. Gonad-Somatic Index (GSI) was calculated to determine spawning periods according to the equation: GSI = [gonads weight $(\mathrm{g}) /$ eviscerated weight (g) $] \times 100$ (Caillier et al. 1986). Hepatosomatic index (HSI) was calculated as: HSI = [liver weight (g)/eviscerated weight (g)] $\times 100$ (Patzner 1980). Size at first maturity $\left(\mathrm{Lm}_{50}\right)$ is defined as the size at which $50 \%$ of fish were mature and was calculated as: $\mathrm{P}=1 /[1+\exp [-$ $\left.\mathrm{b}\left(\mathrm{L}-\mathrm{Lm}_{50}\right)\right]$ ], where, $P$ is the proportion of mature individuals (in stages III/IV, IV and V) at fork length, $b$ is a parameter determining the slope of the maturity curve and $L m_{50}$ is the fork length at which $50 \%$ of the fish are mature. Length-weight relationships were calculated by sex and by both total and eviscerated weight, according to the equation $W=a L^{b}$ (Ricker 1973). The value of the constants $a$ and $b$ was estimated from the log transformed values of length and weight i.e., $\log W=\log a+b \log L$, via least square linear regression (Zar 1984). Student's ttest was used to determine if the coefficient $b$ was significantly different from 3 (Teissier 1948).

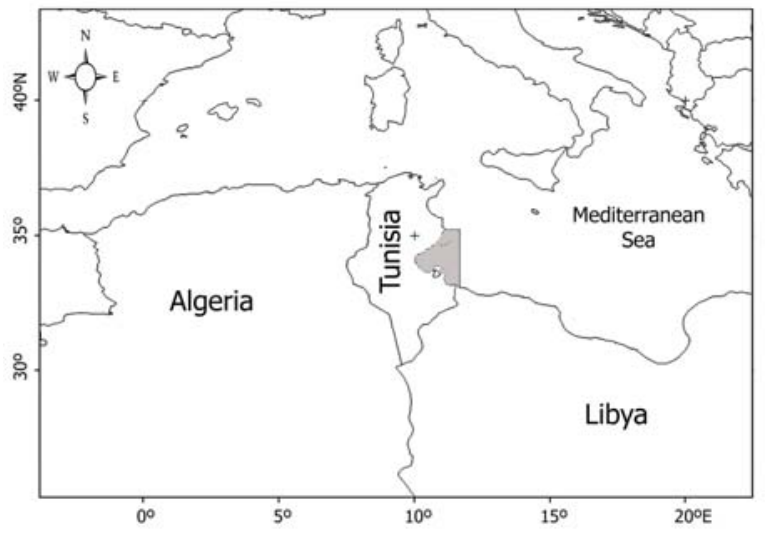

Figure 1. Map of the study area. The gray zone shows the Gulf of Gabes where the little tunny specimes were collected / Mapa de la zona de estudio. La zona gris muestra el Golfo de Gabes en donde se obtuvieron especimenes de bacoreta

\section{ResUlTS}

A total of 397 specimens of Euthynnus alletteratus were collected during the survey. Their lengths (FL) ranged from 36.7 to $97.8 \mathrm{~cm}$ (mean: $52.29 \pm 12.87 \mathrm{~cm})$; female $(\mathrm{N}=$ 244) ranged $36.7-90.5 \mathrm{~cm}$ (mean: $50.53 \pm 9.9 \mathrm{~cm}$ ), while males $(\mathrm{N}=153)$ ranged 37.6 - $97.8 \mathrm{~cm}$ (mean $54.72 \pm$ $15.97 \mathrm{~cm})$. The number of immature individuals represented $16.37 \%$ of the overall sample granted that the number is 65 specimens (immature females $=36$ and immature males = 29). The sex-ratio was higher for females once again in the classes between $62 \mathrm{~cm}$ and $72 \mathrm{~cm}$, and males became larger in number at $72 \mathrm{~cm}$ and more. The sex-ratio observed during 2008 and 2009 was 1:1.59 (61.46\%), which significantly deviated from the expected distribution of $1: 1\left(\chi_{\text {obs }}^{2}=24.65>>\chi_{\text {exp }}^{2}=3.84 ; P<0.05\right)$. When the fish were classified in sizes, with 2 -cm length intervals, females were significantly predominant at lengths smaller than $54 \mathrm{~cm}\left(\chi_{\text {obs }}^{2}=6.32>>\chi_{\text {exp }}^{2}=3.84 ; P\right.$ $<0.05$ ), and males became larger in number in the groups between $54 \mathrm{~cm}$ and $62 \mathrm{~cm}$ length (Fig. 2).

Monthly variation in mean Gonad-Somatic Index (GSI) of females and males occurred between July and October, although less variation was found in the HSI (Fig. 3); for females, GSI showed a pronounced growth reaching a peak in July (3.88), decreasing from September to October, and reaching a minimum value in January (0.032). For males, GSI had a peak also in July (3.45) and a minimum value in November (0.028). The HSI reached a maximum value in May for males (2.33) and females (2.65). The HSI showed slight variations during other months (Fig. 3). These results were also supported by the macroscopic maturing stage 


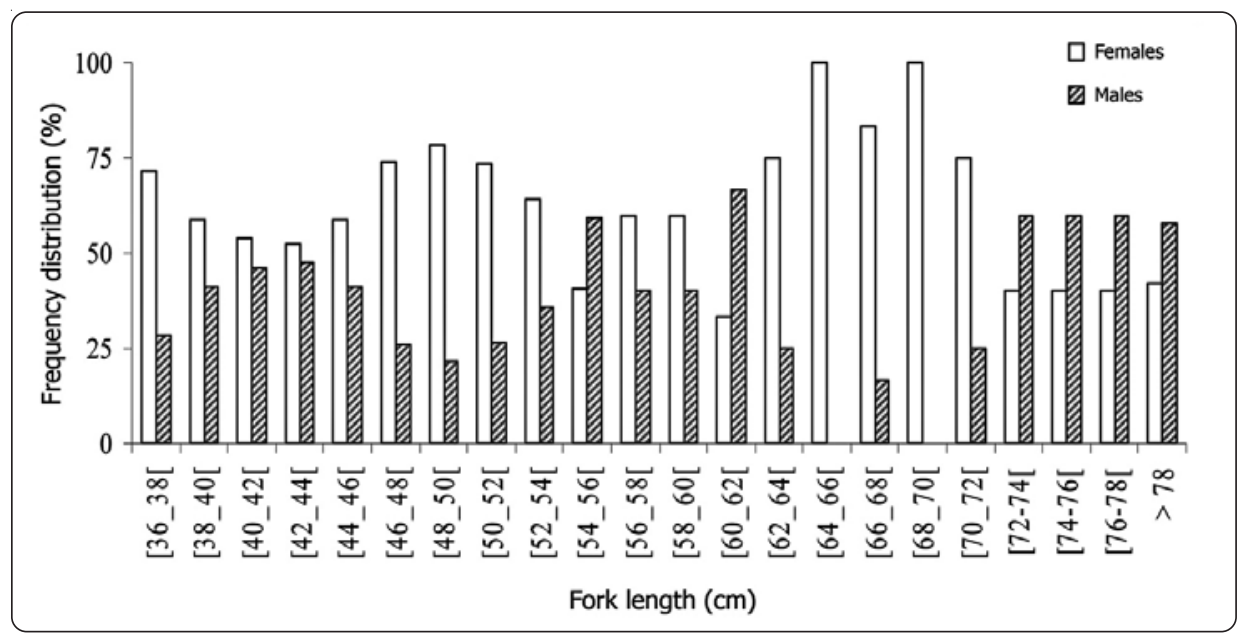

Figure 2. Frequency distribution of fork length by sex in Euthynnus alletteratus / Distribución de la frecuencia de la longitud de horquilla por sexo en Euthynnus alletteratus

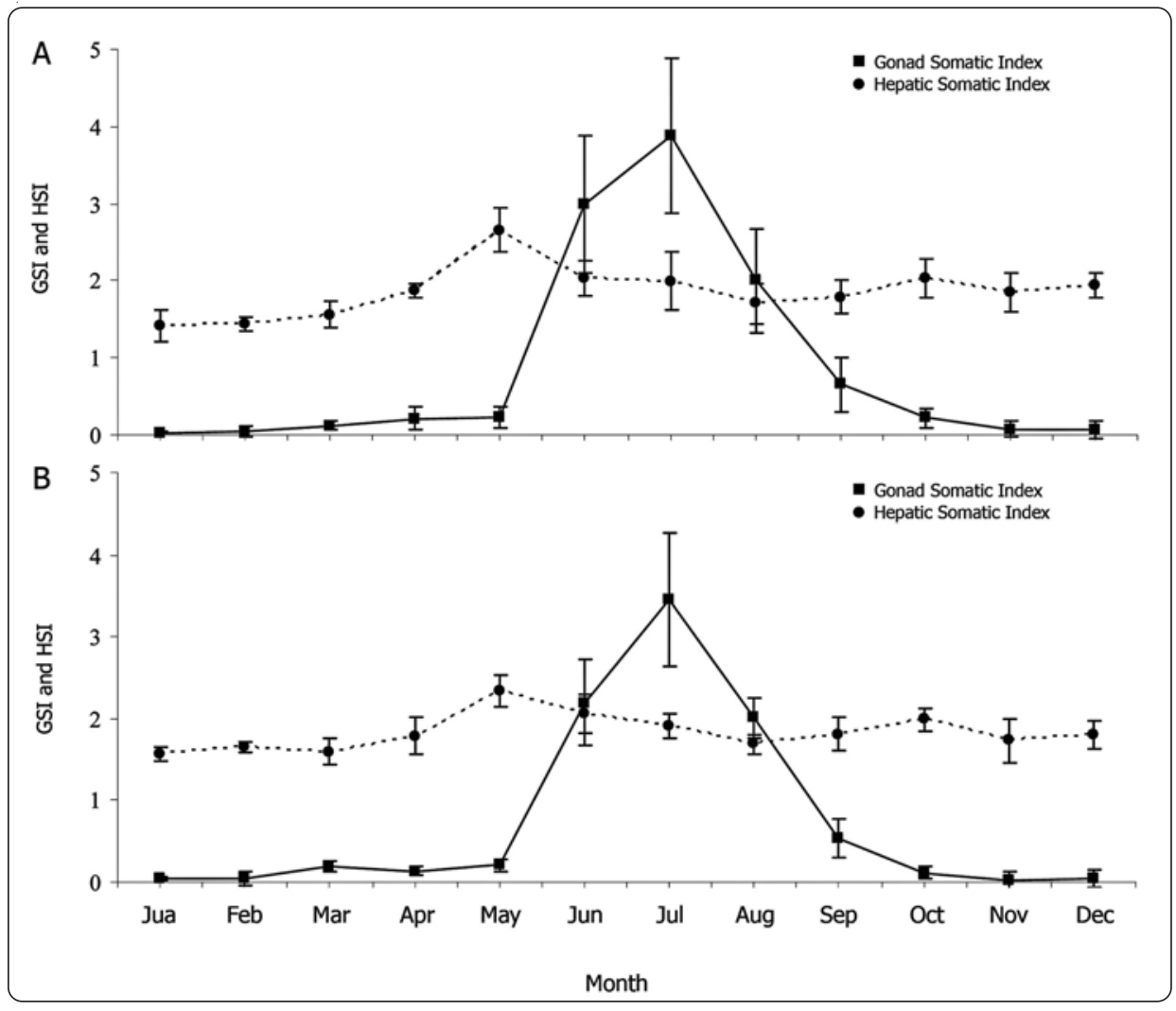

Figure 3. Euthynnus alletteratus mean monthly Gonad-Somatic Index and Hepatic-Somatic Index for A) females and B) males. Vertical bars indicate confidence interval $( \pm 95 \% \mathrm{Cl})$ / Valores promedio mensuales del Índice Gonado-Somático e Índice Hepato-Somático de las A) hembras y B) machos de Euthynnus alletteratus. Las barras verticales indican el intervalo de confianza ( $\pm 95 \%$ IC) 
analysis, that showed mature females and males were common between May and October, with a peak in July (Fig. 4).

The linear regression of total weight $(\mathrm{Wt})$ as a function of eviscerated weight (We) for combined sexes showed a very high correlation coefficient $(\mathrm{We}=0.8906 \mathrm{Wt}+26.71$; $\left.r^{2}=0.996\right)$ suggesting a perfect correlation between the two parameters. The $a$ factor and the allometry coefficient $b$ of the relationships between fork length (L) and total weight (Wt) or eviscerated weight (We) of the all specimens of Euthynnus alletteratus (Table 1, Fig. 5). For females, males and combined sexes, the exponent of the length-weight relationship is significantly lower than the
3 value $(t>>1.96, P<0.05)$ indicating a negative allometric growth. The weight of Gulf of Gabes little tunny increases proportionally slowlier than size. During the spawning period, the allometry coefficient $b$ for the lengthtotal weight was 2.82 for males and 2.86 for combined sexes. These values were significantly lower than 3 , therefore showing a negative allometry $(P<0.05)$. Females have a $b$ value not significantly different from 3 , indicating an isometric allometry ( $\mathrm{b}=2.975, t=0.74, P>0.05)$.

For the population, $50 \%$ of the males and females attained first maturity at 42.8 and $44.8 \mathrm{~cm}$ FL respectively (Fig. 6) indicating that the males generally mature at relatively smaller sizes than the females.

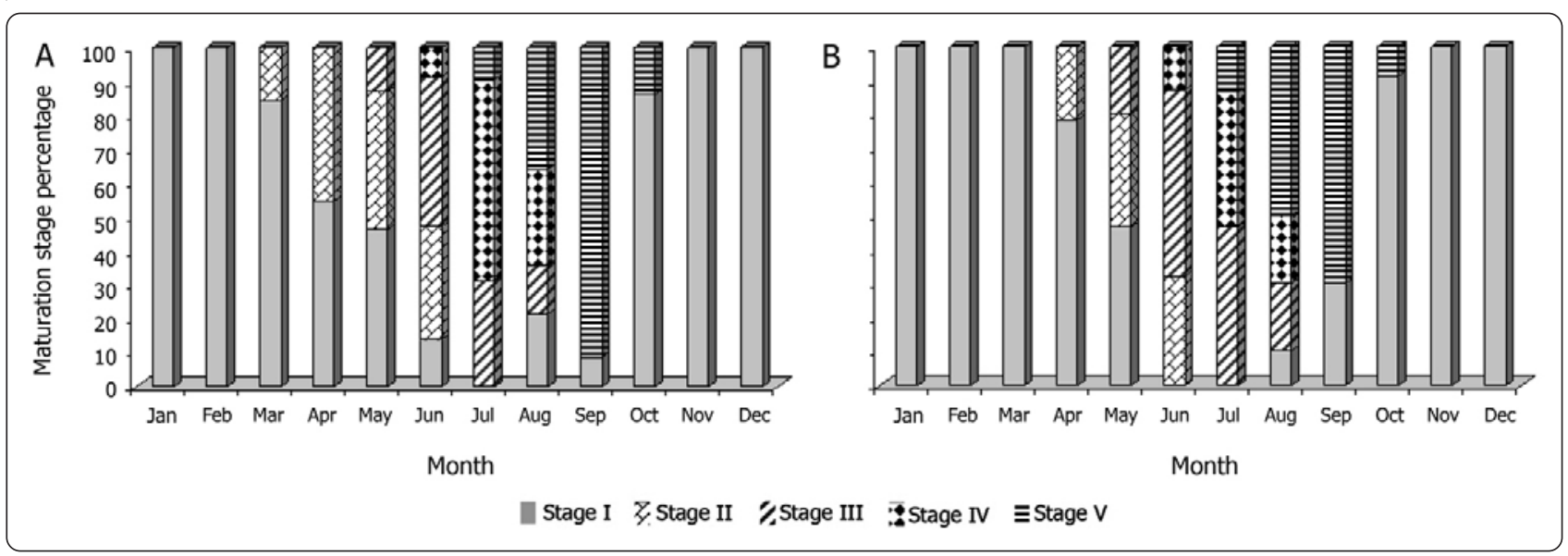

Figure 4. Proportion of Euthynnus alletteratus by maturity stage and month from A) females and B) males / Valores promedio mensuales de la fase reproductora en A) hembras y B) machos de Euthynnus alletteratus

Table 1. Regression parameters $\left(a, b, r^{2}\right)$ of the length-weight relationships of Euthynnus alletteratus in the Gulf of Gabes. (t test; t: stadigraph, +: $\mathbf{P}<\mathbf{0 . 0 5})$, F: females, M: males / Parámetros de regresión $\left(a, b, r^{2}\right)$ de las proporciones Iongitud-peso de Euthynnus alletteratus en el Golfo de Gabes (prueba de t; t: estadígrafo, $+: \mathrm{P}<0,05$ ), $\mathrm{F}$ : hembras, M: machos

\begin{tabular}{|c|c|c|c|c|c|c|c|c|}
\hline Equations & Sex & a & b & sd (b) & $\mathrm{r}^{2}$ & $\mathrm{t}$ & Significance & Allometry \\
\hline \multirow{3}{*}{$\mathrm{Wt}=\mathrm{aL}^{\mathrm{b}}$} & $\mathrm{F}$ & 0.0212 & 2.9183 & 0.0321 & 0.9753 & 2.4635 & + & Negative \\
\hline & M & 0.0301 & 2.8296 & 0.0298 & 0.9835 & 5.4439 & + & Negative \\
\hline & $\mathrm{F}+\mathrm{M}$ & 0.0261 & 2.8645 & 0.0188 & 0.9807 & 6.1807 & + & Negative \\
\hline \multirow{3}{*}{$\mathrm{We}=\mathrm{aL}^{\mathrm{b}}$} & $\mathrm{F}$ & 0.0233 & 2.8669 & 0.0331 & 0.8895 & 2.8443 & + & Negative \\
\hline & M & 0.0302 & 2.8036 & 0.0305 & 0.9848 & 6.5999 & + & Negative \\
\hline & $\mathrm{F}+\mathrm{M}$ & 0.0267 & 2.8329 & 0.0245 & 0.9460 & 4.5254 & + & Negative \\
\hline
\end{tabular}




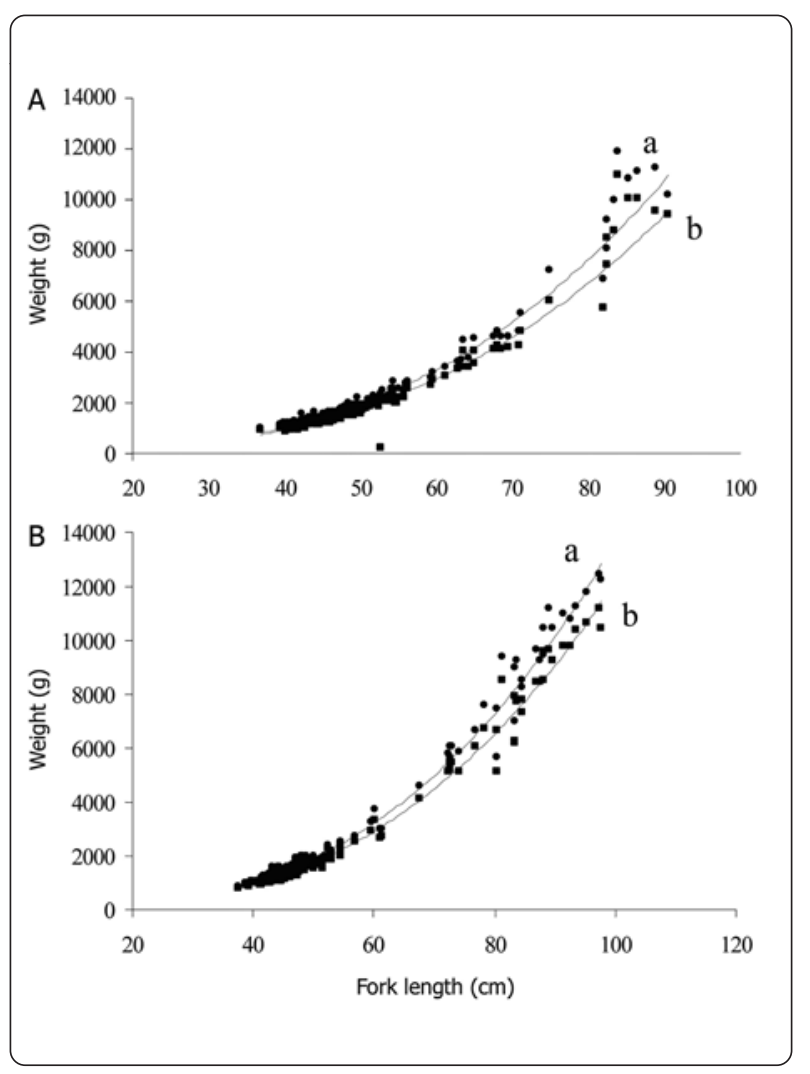

Figure 5. Relationship between fork length with (a) total weight and (b) eviscerated weight of Euthynnus alletteratus $A$ ) females and B) males from the Gulf of Gabes / Relación entre longitud a horquilla con (a) peso total y (b) peso eviscerado en A) hembras y B) machos de Euthynnus alletteratus desde el Golfo de Gabes

\section{Discussion}

According to our knowledge, there is no study reporting biological parameters of Euthynnus alletteratus focused only in the Gulf of Gabes. Based on the mean monthly GSI change, it is clear that the little tunny spawning season in this area is from June to September, with a peak in July coinciding with the rise in water temperature. This fact is confirmed by the macroscopic evaluation of the gonad maturity stage. In fact, this spawning season is based on the presence of large numbers of males and females in stages III-V (mature-spent) of maturity in the JuneSeptember samples, coupled with the very high GSI values recorded during this period. Furthermore, no specimens were found to be mature from November to February. This conclusion is closely related to the results obtained by Hattour (2000) in all the Tunisian coasts. Similar results were found by several authors (Rodriguez-Roda 1979, Cayre \& Diouf 1983). On the other hand, Landau (1965) showed that the spawning period starts early; between May

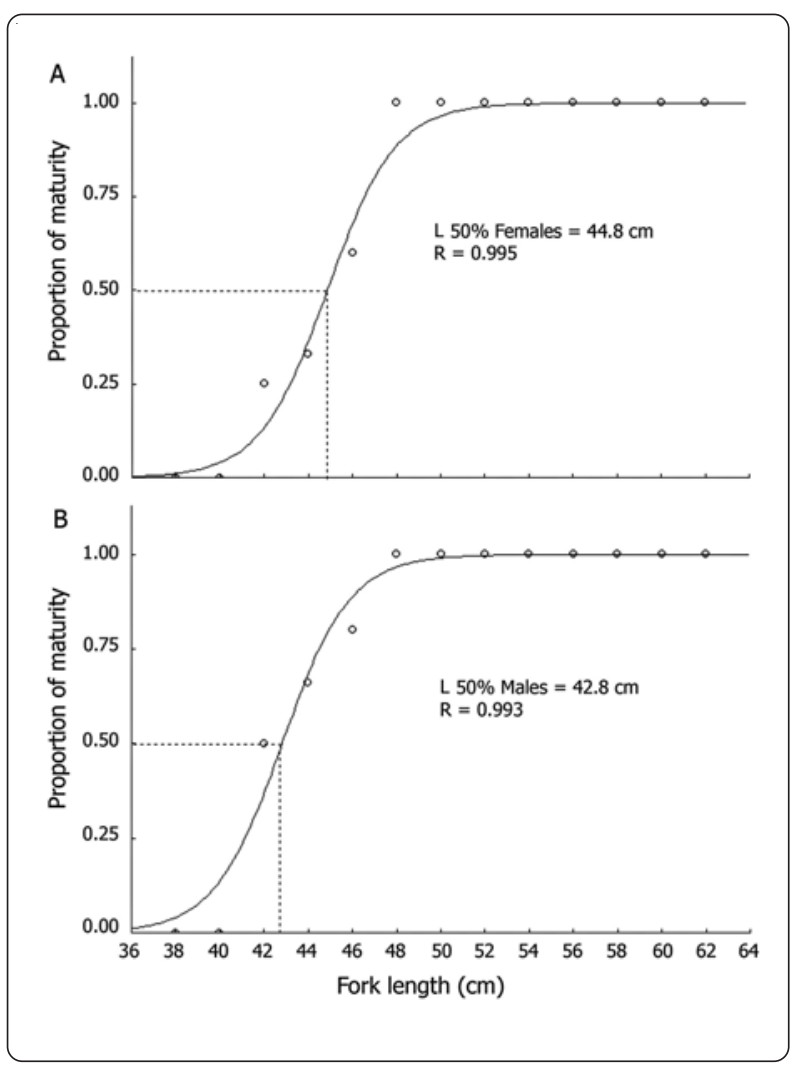

Figure 6. Proportion of mature female (A) and male (B) little tunny in the Gulf of Gabes by fork length classes (L), during 2008 and 2009. Dotted lines show length at 50\% maturity, R: coefficient of correlation / Proporción de hembras maduras (A) y machos (B) de bacoreta en el Golfo de Gabes según su longitud a horquilla (L) durante 2008 y 2009. Las líneas de puntos muestran la talla de madurez del $50 \%$ R: coeficiente de correlación

and September. In eastern and western Atlantic, little tunny spawning has been reported to occur from about April to November (Collette \& Nauen 1983), which is a much more extended period than the interval reported in this study. For males and females, the minimum HSI value, obtained when GSI is highest (June-September), suggests that the liver experiences a weight loss, which may indicate the metabolisation of the hepatic reserves for gonad maturation. Indeed, the accumulation and storage of fat within the liver in the course of ovary maturation is a known phenomenon for many fish species (Bailey 1952, Smith 1957).

Different mortality, growth, sex reversal, seasons, fishing gear and methods influence the sex-ratio variation (Wenner 1972, Wu et al. 2001). The size-combined sexratio of the Euthynnus alletteratus caught in the Gulf of Gabes significantly deviates from the expected 1:1 ratio, with a female percentage of $61.14 \%$. This suggests that 
there is a difference in the availability of both sexes for the fishery. This may be because of a spatial segregation of sexes or because of different behaviour in relation to the gear (Mendonça et al. 2006). Except in June, at the beginning of the reproduction period, females outnumber males throughout the year. This result is similar to that found by Hajjej et al. (2009) for the same species in Tunisian waters in general. The increment of males with high GSI value during this period can be due to the tough competition strategy between males, resulting in the selection of the fittest for reproduction (Sousa et al. 2003). The dominance of females has been proven by Kahraman et al. (2008) in eastern Mediterranean and Valeiras et al. (2008) in western Mediterranean Sea. However, the sexratio was for males in Tunisian waters (Hattour 2000) and in eastern Atlantic Ocean (Gaykov \& Bokhanov 2008). This change in the sex-ratio could be due to differences in fishing gear and methods used (Wu et al. 2001). The sexratio analysis by length indicates an alternation of dominance between females and males, with female dominance in most of the size classes, except between 54 and $62 \mathrm{~cm}$, and in the size classes larger than $74 \mathrm{~cm}$, where males are predominant. The same phenomenon of male preponderance in the larger size classes has also been reported for other tuna species, such as yellowfin tuna Thunnus albacares (Sun et al. 2005), albacore tuna Thunnus alalunga (Wu \& Kuo 1993, Ramon \& Bailey 1996), Atlantic bluefin tuna Thunnus thynnus (Clay 1991), and bigeye tuna Thunnus obesus (Nikaido et al. 1991).

According to this study, the smallest female and male mature specimens observed were $38.7 \mathrm{~cm}$ and $39.4 \mathrm{~cm}$ respectively, being slightly shorter than the values reported earlier by Hattour (2000), who indicated that females of $40 \mathrm{~cm}$ began to mature, while males began to mature at 41 $\mathrm{cm}$. Diouf (1980) determined that specimens at $60 \mathrm{~cm}$ of length were fully mature in Senegal. This size is significantly larger than the $49.2 \mathrm{~cm}$ found in this study, and the $49 \mathrm{~cm}$ from the Tunisian waters (Hattour 2000). It is interesting to note that macroscopic staging is not recommended to be the most appropriate method to estimate maturity because mature but post-spawning or resting females may be misclassified as immature (Schaefer 2001).

In Tunisian waters, 50\% maturity is reached by age two at size of $42.9 \mathrm{~cm}$ for females and $39.7 \mathrm{~cm}$ for males (Hattour 2000). Chur (1973) estimated maturity length at $50 \%$ for little tunny in the Gulf of Guinea to be $44 \mathrm{~cm}$ for males and $42 \mathrm{~cm}$ for females. Our estimated length at 50\% maturity was $42.8 \mathrm{~cm} \mathrm{Fl}$ and $44.8 \mathrm{~cm} \mathrm{Fl}$ for males and females respectively, which is substantially lower than the estimates for southern Spain: 56 cm Fl (Rodriguez-Roda 1966). Natural fish stocks are complex mixtures of genotypes, responding differently to fishing pressure, which somewhat erodes natural genetic diversity in order to select the genotypes that are better able to withstand the impacts, and the change in size at maturity is one of the more worrisome genetic changes (Walters \& Martell 2004). From the present study, it is evident that females $E$. alletteratus reach sexual maturity at a larger size than the males, similar to the report on the same species from Tunisian waters (Hattour 2000). This could ensure that the fish have more accommodative capacity for increased egg production. It is also evident from the present study, that males mature at smaller sizes than females. This could suggest either that at some stage the males grow more slowly than the females, or that the males mature earlier than the females.

The difference in size at maturity between this work and Hattour (2000), thus, may reflect the effects of decades of fishing pressure upon E. alletteratus in Tunisian waters. The current fishing pressure is apparently planned seeing as little tunny was recently described as a priority species by the Scientific Advisory Committee of CGPM (FAO 2009). Further, according to Walker \& Ellis (1998), the negative effects of exploitation, may be counteracted by compensatory mechanisms such as density dependent changes in fecundity, age or size at maturation.

In this study, the relationships established using eviscerated or total fish weights showed always an allometric growth (negative allometry). This conclusion is similar in the Aegean Sea (Kahraman \& Oray 2001), in the eastern Mediterranean Sea (Kahraman 2005), in the north-eastern Mediterranean (Kahraman et al. 2008) and in the south-east of Spain (Macias et al. 2006) for the same species. The relatively low values of $b(\mathrm{~b}<3)$ can be attributed to the combination of one or more of the following factors, such as temperature, salinity, stage of maturity, or food abundance (Andrade \& Campos 2002). The $b$ values for both weights (total and eviscerated weight) for the combined sexes found in this study are much lower than those obtained by Hattour $(1984,2000,2009)$ for the Tunisian coasts. These differences are probably related to the different size structure of little tunny population included in the length-weight relationship analysis, or with interannual changes in the nutritional condition of the organisms (Isajlovic et al. 2009). Furthermore, when the monthly $b$ values were analysed on the spawning period (June-September) it was observed that the $b$ values for 
males and both sexes were significantly different from three, which supports the trend observed during the global study period. However the $b$ value, for females, was relatively higher, indicating an isometric growth may be due to the significant increase in the studied ovarian weight. This increase in female weight during the spawning period is obviously linked to the reproduction process (Bottari 2004).

The contribution of this study lays in the description of some characteristics of the reproductive biology of Euthynnus alletteratus in the Gulf of Gabes. The information obtained could be of use in the development of fishery management strategies for this species.

\section{ACKNOWLedgments}

Financial support was given by the Marine Living Resources Laboratory of the National Institute of Marine Sciences and Technologies (I.N.S.T.M). We are grateful to Susana Artieda for the English review.

\section{Literature Cited}

Andrade HA \& RO Campos. 2002. Allometry coefficient variations of the length-weight relationship of skipjack tuna (Katsuwonus pelamis) caught in the southwest Atlantic. Fisheries Research 55: 307-312.

Bailey BE. 1952. Marine oils with particular reference to those of Canada. Bulletin, Fisheries Research Board of Canada 89: 1-143.

Bottari T, P Rinelli, D Giordano \& S Greco. 2004. Lengthweight relationship and maturity of the Atlantic mackerel Scomber scombrus from the Adriatic Sea (Eastern Mediterranean). Cahiers de Biologie Marine 45: 49-5.

Bradai MN, M Ghorbel \& A Bouain. 1995. Aperçu sur l'activité de pêche dans le gouvernorat de Sfax. Cahier de Série Géographique 1: 211-236.

Caillier GM, MS Love \& AW Ebeling. 1986. Fishes: a field and laboratory manual on their structure, identification, and natural history, 194 pp. Wadsworth publishing Company, Belmont.

Cayré PM \& T Diouf. 1983. Estimating age and growth of little tunny, Euthynnus alletteratus, off the coast of Senegal using dorsal fin spine sections. NOAA Technical Report, NMFS 8: 105-110.

Chur VN. 1973. Some biological characteristics of little tunny (Euthynnus alletteratus Rafinesque, 1810) in the eastern part of the tropical Atlantic. Collective Volume of Scientific Papers of International Commission for the Conservation of Atlantic Tunas 1: 489-500.

Clay D. 1991. Atlantic bluefin tuna (Thunnus thynnus). A review. Inter-American Tropical Tuna Commission Special Report 7: 89-180.
Collette BB \& CE Nauen. 1983. FAO species catalogue. Vol. 2. Scombrids of the world. An annotated and illustrated catalogue of tunas, mackerels, bonitos and related species known to date, 137 pp. FAO, Rome.

Diouf T. 1980. Premières données relatives a l'exploitation et a la biologie de quelques 'Petits thonidés et espèces voisines': Euthynnus, Sarda, Scomberomorus au Sénégal. Collective Volume of Scientific Papers of International Commission for the Conservation of Atlantic Tunas 15(2): 327-336.

FAO. 2009. FAO Commission générale des pêches pour la Méditerranée. Rapport CGPM 33: 1-132. FAO, Rome.

Frade F \& E Postel. 1955. Contribution à l'étude de la reproduction des scombridés et thonidés de l'Atlantique tropical. Rapport du Conseil International pour l’Exploration de la Mer 137: 33-35.

Gaykov VZ \& DV Bokhanov. 2008. The biological characteristic of Atlantic black skipjack (Euthynnus alletteratus) of the eastern Atlantic Ocean. Collective Volume of Scientific Papers of International Commission for the Conservation of Atlantic Tunas 62(5): 1610-1628.

Hajjej G, A Hattour, H Allaya, O Jarboui \& A Bouain. 2009. Sex-ratio, relation taille-masse et coefficient de condition de la thonine commune Euthynnus alletteratus (Rafinesque, 1810) des cotes tunisiennes. Bulletin de l'Institut National des Sciences et Technologie De la Mer 36: 39-44.

Hattour A. 1984. Analyse de l'âge, de la croissance et des captures des thons rouges (Thunnus thynnus) et des thonines (Euthynnus alletteratus) pêchés dans les eaux Tunisiennes. Bulletin de l'Institut National des Sciences et Technologie de la Mer 11: 27-61.

Hattour A. 2000. Contribution à l'étude des poissons pélagiques des eaux tunisiennes. Thèse de doctorat en sciences biologiques, Faculté des sciences de Tunis, Tunisie, 344 pp.

Hattour A. 2009. Les thons mineurs tunisiens : Etude biologiques et pêche. Collective Volume of Scientific Papers of International Commission for the Conservation of Atlantic Tunas 64(7): 2230-2271.

Isajlovic I, N Vrgoc, B Zorica, M Peharda, S KrstulovicSifner \& C Piccinetti. 2009. Age, growth and lengthweight relationship of Coelorinchus caelorhincus (Risso, 1810) in the Adriatic Sea. Acta Adriatica 50(1): 23-30.

Kahraman AE. 2005. Investigation on little tunny (Euthynnus alletteratus, Rafinesque 1810) in the Eastern Mediterranean Sea. Collective Volume of Scientific Papers of International Commission for the Conservation of Atlantic Tunas 58: 502-509.

Kahraman AE \& IK Oray. 2001. Age and growth of Atlantic little tunny (Euthynnus alletteratus Raf., 1810) in Turkish waters. Collective Volume of Scientific Papers of International Commission for the Conservation of Atlantic Tunas 49: 719-732. 
Kahraman AE, TZ Alicli, T Akayli \& IK Oray. 2008. Reproductive biology of little tunny, Euthynnus alletteratus (Rafinesque, 1810), from the north-eastern Mediterranean Sea. Journal Applied of Ichthyology 24: 551-554.

Klawe WL, JJ Pella \& WS Leet. 1970. The distribution, abundance and ecology of larval tunas from the entrance to the Gulf of California. Bulletin of Inter-American Tropical Tuna Commission 14: 507-544.

Landau R. 1965. Determination of age and growth rate in Euthynnus alletteratus and Euthynnus affinis using vertebrae. Commission Internationale pour l'Exploration Scientifique de la mer Méditerranée 8: 241-244.

Macias D, MJ Lema, MJ Gomez-Vives, JM Ortiz de Urbina \& JM de la Serna. 2006. Some biological aspects of small tunas (Euthynnus alletteratus, Sarda sarda \& Auxis rochei) from the south western Spanish Mediterranean traps. Collective Volume of Scientific Papers of International Commission for the Conservation of Atlantic Tunas 59: 579-589.

Macias D, JM Ortiz de Urbina, MJ Gómez-Vives, L Godoy \& JM de la Serna. 2009. Size distribution of Atlantic little tunny (Euthynnus alletteratus) caught by south western Mediterranean traps and recreational trawl fishery. Collective Volume of Scientific Papers of International Commission for the Conservation of Atlantic Tunas 64(7): 2284-2289.

Mendonça A, E Isidro, G Menezes, M Rui-Pinho, O Melo \& S Estácio. 2006. New contribution to the reproductive features of bluemouth Helicolenus dactylopterus dactylopterus from the northeast Atlantic (Azores Archipelago). Scientia Marina 70(4): 679-688.

Nikaido H, N Miyabe \& S Ueyanagi. 1991. Spawning time and frequency of bigeye tuna, Thunnus obesus. Bulletin of National Research Institute of Fisheries Science, Japan 28: 47-73.

Patzner RA. 1980. Cyclical changes in weight and fat content of the liver and their relationship to reproduction in the Hagfish Eptatretus burgeri (Cyclostomata). Acta Zoologica 6: $157-160$

Ramon D \& K Bailey. 1996. Spawning seasonality of albacore, Thunnus alaunga, in the South Pacific Ocean. Fishery Bulletin 94(4): 725-733.

Rey JC \& JL Cort. 1981. Migration de bonitos (Sarda sarda) y bacoreta (Euthynnus alletteratus) entre el Mediterraneo y el Atlantico. Collective Volume of Scientific Papers of International Commission for the Conservation of Atlantic Tunas 15(2): 346-347.

Ricker WE. 1973. Linear regressions in fishery research. Journal of the Fisheries Research Board of Canada 30: 409434.

Rodriguez-Roda J. 1966. Estudio de la bacoreta, Euthynnus alletteratus (Raf.), bonito, Sarda sarda (Bloch) y melva Auxis thazard (Lac.), capturados por las almadrabas españolas. Investigacion Pesquera, España 30: 247-92.

Rodriguez-Roda J. 1979. Edad y crecimiento de la Bacoreta, Euthynnus alletteratus (Raf.) de la Costa Sudatlántica de España. Investigacion Pesquera, España 43: 591-599.

Schaefer KM. 2001. Reproductive biology of tunas. In: Block BA \& ED Stevens (eds), Tunas: ecological physiology and evolution, pp 225-270. Academic Press, New York.

Smith S. 1957. Early development and hatching. In: Brown ME (eds). The physiology of fishes 1: 323-359. Wiley, New York.

Sousa L, JP Barreiros, MSC Soares, M Hostim-Silva \& RS Santos. 2003. Preliminary notes on the reproductive biology of the lizardfish, Synodus saurus (Actynopterygii: Synodontidae) in the Azores. Cybium 27(1): 41-45.

Stequert B. 1976. Etude de la maturité sexuelle, de la ponte et de la fécondité du listao (Katsuwonus pelamis) de la côte nord-ouest de Madagascar. Cahier Oceanographique 14(3): 227-247.

Sun CL, WJ Wang \& Y Su-Zan. 2005. Reproductive biology of the female yellowfin tuna Thunnus albacares in the western Pacific Ocean, 15 pp. Western and Central Pacific Fisheries Commission Scientific Committee, Noumea.

Teissier G. 1948. Allometry relationships: Its statistical and biological significance. Biometrika 4: 14-18.

Valeiras X, D Macias, MJ Gómez, L Lema, D Godoy, JM Ortiz de Urbina \& JM de la Serna. 2008. Age and growth of atlantic little tunny (Euthynnus alletteratus) in the western Mediterranean sea. Collective Volume of Scientific Papers of International Commission for the Conservation of Atlantic Tunas 62(5): 1638-1648.

Walker PA \& J Ellis. 1998. Ecology of rays of the north-eastern Atlantic. In: Biology of skates. Proceedings of the Biology of Skates Symposium (New Orleans, 1996), pp 7-29, Princeton Press, New Orleans.

Walters CJ \& SJD Martell. 2004. Strategies requirements for sustainable fisheries. In: Walters CJ \& SJD Martell (eds). Fisheries ecology and management, pp 43-64. Princeton University Press, Princeton.

Wenner A. 1972. Sex ratio as a function of size in marine crustaceans. American Naturalist 106: 321-350.

Wu CL \& CL Kuo. 1993. Maturity and fecundity of albacore from the Indian Ocean. Journal of the Fisheries Society of Taiwan 20(2): 135-152.

Wu CC, WC Su \& T Kawasaki. 2001. Reproductive biology of the dolphin fish Corphaena hippurus on the east coast of Taiwan. Fisheries Science 67: 784-793.

Zar JH. 1984. Biostatistical analysis, 718 pp. Prentice-Hall, Englewood Cliffs.

Recibido el 4 de mayo de 2010 y aceptado el 30 de julio de 2010

406 Hajjej et al.

Biology of Euthynnus alletteratus 